\title{
Assess the Cervical Re-Position Sense Accuracy among the Normal Individuals
}

\author{
Palaparthi V S Phanindra Akhil and Ayyappan Jayavel* \\ SRM college of Physiotherapy, SRM University, India
}

Submission: June 01, 2017; Published: June 08, 2017

*Corresponding author: Ayyappan Jayavel, SRM College of Physiotherapy, SRM University, Chennai, India, Email: ayyappanpt@gmail.com

\section{Abstract}

Background: Although the role of afferent input from cervical muscles on the control of posture and locomotion is recognized, it is surprising that there is absence of data reporting whether joint position sense at the cervical level is impaired in older healthy adults.

Objective: to assess the cervical re-position sense accuracy among the normal individuals. Design: Observational Study.

Methods: 140 samples were taken in both males and females which were divided into 7 groups depending upon their age criteria. Each group had 20 individual which were asked to perform neck repositioning accuracy test.

Results: It shows age group from $10-19 \mathrm{x}$ axis $8.63 \pm 5.54,10-19 \mathrm{y}$ axis $10.7 \pm 6.14$, and $20-29 \mathrm{x}$ axis $7.61 \pm 5.34,20-29 \mathrm{y}$ axis $7.28 \pm 4.23$, and $30-39 \mathrm{x}$ axis $8.03 \pm 6.19,30-39 \mathrm{y}$ axis $7.61 \pm 5.63$, and $40-49 \mathrm{x}$ axis $9.40 \pm 6.33,40-49$ y axis $7.31 \pm 5.08$, and $50-59 \mathrm{x}$ axis $8.15 \pm 5.86,50-59 \mathrm{y}$ axis $8.03 \pm 5.89$, and $60-69 \mathrm{x}$ axis $9.38 \pm 5.66,60-69 \mathrm{y}$ axis $7.93 \pm 5.70$, and $70-79 \mathrm{x}$ axis $8.78 \pm 5.98,70-79 \mathrm{y}$ axis $9.71 \pm 6.21$.According to ANOVA 'p' value is .668 statistically not significant

Conclusion: This study was designed specifically to compare cervical joint position sense in normal individuals. There was increase in accuracy of cervical reposition sense in adults than in older age.

Keywords: Cervical; Cervical re-position

\section{Introduction}

In modern society lot of people have using computer and frequent use of cell phones those have musculoskeletal disorders of neck and shoulder position .Postural stability is essential factor in physical therapy as the changes in posture lead the change in muscle activities or load on each joint according to the positions of joint related to alignment of human body and these changes have impact on musculoskeletal system [1]. The compensatory action of neck and head changes depends on position of person whether standing or sitting [2]. Position of head and neck depends on the tension in both neck extensor muscles and neck flexor muscles, any unbalance in these two group of muscles changes in position of head in musculoskeletal system [3].

Cervical position depends on proprioception of joints, muscles, tendons because position and motion that were delivered by receptors located in muscles, tendons and joints [4]. The term "proprioception" originally defined by Sherrington in 1906 as "the perception of joint and body movement as well as position of the body or body segments in space" [5].
Proprioception involves mechanoreceptors present in (articular muscles and tendons) [6,7]. Proprioception changes from younger age group to elderly age group in normal individuals [8]. There is any damage on muscles or joints may bring about a dysfunction on muscle spindle and proprioception could decrease according to a structural change caused a chemical change or damage around the muscle spindle, if there is any damage in proprioception it will be difficult to make a proper response based on collaboration with related muscles [9].

The proprioception may be divided into muscle, skin, and joint proprioception and it gives information from the joints, tendons, ligaments, muscles and skin. Both muscle spindle and golgi tendon organ are dynamic receptor of muscles and tendons, main function of muscle spindle is to accept the changes in length of muscle and the speed of change which are delivered to nervous system \& main function of golgi tendon organ is to detect the changes in tension between muscle tendon units [10]. Cervical proprioception depends on muscles surrounded by cervical vertebra which facilitates the head and neck movement and muscles in depth which are attached to the 
cervical vertebra as they are located in depth [11]. Many neck muscles have certain number of muscle spindles per unit, so it can be assumed that the muscles are requested to have high level function of proprioception [12]. Therefore, this study aims to identify cervical position and accuracy changes from younger age to older age group [13-15].

\section{Methodology}

This study received institutional ethical approval from SRM college of Physiotherapy, SRM University. All participants provided informed written consent.

a) Participants: 140 subjects were recurred for this study. Subjects who had an external injury or neurologic damage around neck, cervical spine and recent facture were excluded, because such injuries could have an impact on results of the study. Subjects included were normal healthy individuals (10-80 years).

b) Outcome measure: Head repositioning accuracy and neck proprioception was measured using a cervical range of motion (CROM) tester. The CROM tester has been devised to measure the cervical range of motion, and it also helps to carry out an objective measurement of neck flexion, extension, lateral flexion and rotation.

\section{Procedure}

Subjects were divided into 20 in each group with difference of 10 years i.e (10-19,20-29,30-39,40-49,50-59,60-69,70-79). before measuring the cervical accuracy subjects were seated with backrest and neutral head position should be maintained. Graph sheet will be attached to the wall $2 \mathrm{~cm}$ away in front of subject for measuring the head repositioning accuracy. Subject should sit in erect with head in neutral position accordance to graph sheet. after wearing helmet with a laser pointer attached on helmet , the subjects was asked to aim the beam at the center of the graph sheet .now subjects were asked to perform the active movement in one plain a) In flexion and extension take first neutral value note the values on both $\mathrm{x}-1$ axis and $\mathrm{y}-1$ axis. Now ask subjects to close their eyes and $t$ do flexion movement in neutral position and note that point on graph sheet $\mathrm{x}-2$ axis and $\mathrm{y}-2$ axis. Distance between both $\mathrm{x}$ axis difference and $\mathrm{y}$ axis difference will be the head position changes. This same procedure should follow for lateral flexion and rotation to find the neck position accuracy in all different planes and movements [16].

a. Data Analysis: Statistics were done by using SPSS (20 version) for windows. By descriptive statistics used for mean, frequency difference in age group ANOVA was used for analyses difference between the age group.

\section{Results}

It shows age group from $10-19 \mathrm{x}$ axis $8.63 \pm 5.54,10-19 \mathrm{y}$ axis $10.7 \pm 6.14$, and $20-29 \mathrm{x}$ axis $7.61 \pm 5.34,20-29$ y axis $7.28 \pm 4.23$, and $30-39 \mathrm{x}$ axis $8.03 \pm 6.19,30-39 \mathrm{y}$ axis $7.61 \pm 5.63$, and 40 -
$49 \mathrm{x}$ axis $9.40 \pm 6.33,40-49 \mathrm{y}$ axis $7.31 \pm 5.08$, and $50-59 \mathrm{x}$ axis $8.15 \pm 5.86,50-59$ y axis $8.03 \pm 5.89$, and $60-69 \mathrm{x}$ axis $9.38 \pm 5.66$, $60-69$ y axis $7.93 \pm 5.70$, and $70-79 \mathrm{x}$ axis $8.78 \pm 5.98,70-79$ y axis $9.71 \pm 6.21$. According to ANOVA ' $p$ ' value is .668 statistically not significant (Tables 1 \& 2).

Table 1: Age varies name.

\begin{tabular}{|c|c|c|c|c|c|}
\hline S.no & \multicolumn{2}{|c|}{ Age varies name } & Number & Mean & $\begin{array}{c}\text { Std. } \\
\text { Deviation }\end{array}$ \\
\hline & Age & Axis & & & \\
\hline 1 & $10-19$ & X axis & 20 & 8.63 & 5.54 \\
\hline 2 & $10-19$ & Y axis & 20 & 10.73 & 6.14 \\
\hline 3 & $20-29$ & X axis & 20 & 7.61 & 5.34 \\
\hline 4 & $20-29$ & Y axis & 20 & 7.28 & 4.23 \\
\hline 5 & $30-39$ & X axis & 20 & 8.03 & 6.19 \\
\hline 6 & $30-39$ & Y axis & 20 & 7.61 & 5.63 \\
\hline 7 & $40-49$ & X axis & 20 & 9.40 & 6.33 \\
\hline 8 & $40-49$ & Y axis & 20 & 7.31 & 5.08 \\
\hline 9 & $50-59$ & X axis & 20 & 8.15 & 5.86 \\
\hline 10 & $50-59$ & Y axis & 20 & 8.03 & 5.89 \\
\hline 11 & $60-69$ & X axis & 20 & 9.38 & 5.66 \\
\hline 12 & $60-69$ & Y axis & 20 & 7.93 & 5.70 \\
\hline 13 & $70-79$ & X axis & 20 & 8.78 & 5.98 \\
\hline 14 & $70-79$ & Y axis & 20 & 9.71 & 6.21 \\
\hline
\end{tabular}

Table 2: Anova.

\begin{tabular}{|c|c|c|c|}
\hline Age groups & Df & F & Sig. P value \\
\hline Between age groups & 7 & .705 & .668 \\
\hline
\end{tabular}

\section{Discussion}

The purpose of the study is to find cervical position sense accuracy among normal individuals in different age groups. Proprioception system which maintain the position of the joints, muscular changes, changes in neural plasticity. Age related deterioration in the proprioception system is well noticed. Based on descriptive statistical analysis in different age groups by using ANOVA, found that adults having accuracy to maintain cervical position than in older age. Increased afferent input from muscle receptors, number of muscle spindles and total number of intrafusal muscle fibers, due to increased physical activity in adult age compare to older age, physical activity increases changes in depth of the tissues it doesn't indicate increase in number of mechanoreceptors, which maintain proprioception present in muscle spindles, joint capsule, ligaments and tendons [17-22].

Due to physical activity, morphology of mechanoreceptors changes which increases proprioception in adults Based 
on different age groups younger age had mild changes in proprioception because of neural plasticity and adults had increased in proprioception due to physical activity. Older age had deterioration of proprioception due to decrease in the dynamic response of muscle spindle, decreases in the total number of intrafusal muscle fibers and nuclear chain fibers per spindle, increases in spindle capsule thickness, neuromuscular performance decline, progressive loss of the dendrite system in the motor cortex and losses number of neurons [17].

\section{Conclusion}

This study was designed specifically to compare cervical joint position sense in normal individuals. There was increase in accuracy of cervical reposition sense in adults than in older age. Further studies were recommended to take more number of samples to get statistical significant.

\section{References}

1. Moon SE (2004) General coordinative manipulation. ( $1^{\text {st }}$ edn). Jungdam Media, Seoul, South Korea.

2. Kendall FP, McCreary EK, Provance PG, Rodgers MM, Romani WA (2005) Muscles: testing and function with posture and pain. $\left(5^{\text {th }}\right.$ edn). LWW, Baltimore, USA.

3. Burgess-Limerick R, Plooy A, Ankrum DR (1998) The effect of imposed and self-selected computer monitor height on posture and gaze angle. Clin Biomech (Bristol, Avon) 13: 584-592.

4. Kim SY, Lee HJ (2006) Literature review on the association between a cervical dysfunction and the change of neuromuscular control activity. J Korean Acad Orthoped Man Ther 12: 57-67.

5. Sherrington CS (1907) On the proprioceptive system, especially in its reflex aspect. Brain 29: 467-482.

6. Gandevia SC, Burke D (1992) Does the nervous system depend on kinesthetic information to control natural limb movements? Behavioral and Brain Sciences 15: 614-632.

7. Stump JL (2004) The neuroarticular lesion in the elderly: a condensed literature review. J Manipulative Physiol Ther 27: e10.

8. Bove M, Courtine G, Schieppati M (2002) Neck muscle vibration and spatial orientation during stepping in place in humans. J Neurophysiol 88: 2232-2241.

9. Vuillerme N, Pinsault N, Vaillant J (2005) Postural control during quiet standing following cervical muscular fatigue: effects of changes in sensory inputs. Neurosci Lett 378: 135.

10. GosselinG, RassoulianH, Brown I (2004) Effects of neck extensor muscles fatigue on balance. Clin Biomech (Bristol, Avon) 19: 473-479.

11. Shankar K. Exercise prescription. ( $1^{\text {st }}$ edn). Hanley \& Belfus, Philadelphia, USA, pp. 199.

12. Edin B (2001) Cutaneous afferents provide information about knee joint movements in humans. J Physiol 531: 289-297.

13. Kisner C, Colby LA (2002) Therapeutic exercise: foundations and techniques. $\left(4^{\text {th }}\right.$ edn). FA Davis, Philadelphia, USA.

14. Boyd-Clark LC, Briggs CA, Galea MP (2002) Muscle spindle distribution, morphology, and density in longus colli and multifidus muscles of the cervical spine. Spine (Phila Pa 1976) 27: 694-701.

15. DeStefano LA (2011) Greenman's principles of manual medicine. $\left(4^{\text {th }}\right.$ edn). Lippincott Williams \& Wilkins, Philadelphia, USA.

16. Kyung Wok Kang, Dae Won Kang, Gu Ye Kwon (2015) Stated that The Impact of head repositioning accuracy and proprioception on cervical stabilization exercise in healthy adults. Physical therapy rehabilitation science 4(1): 49-54.

17. Fernando Ibeeiro, Jose Oliveira (2007) Stated that aging effects on joint proprioception: the role of physical activity in prroproception preservation

18. Heikkila H, Astrom PG (1996) Cervicocephalic kinesthetic sensibility in patients with whiplash injury. Scand J Rehabil Med 28: 133-138.

19. Stump JL (2004) The neuroarticular lesion in the elderly: a condensed literature review. J Manipulative Physiol Ther 27: e10.

20. Revel M, Andre-Deshays C, Minguet M (1991) Cervicocephalic kinesthetic sensibility in patients with cervical pain. Arch Phys Med Rehabil 72: 288-291.

21. Pinsault N, Vaillant J, Virone G, Caillat-Miousse JL, Lachens L, et al. (2006) Cervicocephalic relocation test: a study of performance stability. Ann Readapt Med Phys 49: 647-651.

22. Mergner T, Schweigart G, Botti F, Lehmann A (1998) Eye movements evoked by proprioceptive stimulation along the body axis in humans. Exp Brain Res 120: 450-460.

\section{Your next submission with Juniper Publishers will reach you the below assets}

- Quality Editorial service

- Swift Peer Review

- Reprints availability

- E-prints Service

- Manuscript Podcast for convenient understanding

- Global attainment for your research

- Manuscript accessibility in different formats

( Pdf, E-pub, Full Text, Audio)

- Unceasing customer service

Track the below URL for one-step submission https://juniperpublishers.com/online-submission.php 